\title{
In memoriam: Professor A.A. Ramezanianpour an active editorial member of the Asian Journal of Civil Engineering
}

\section{Ali Kaveh $^{1}$}

Accepted: 26 May 2021 / Published online: 11 June 2021

(c) The Author(s), under exclusive licence to Springer Nature Switzerland AG 2021

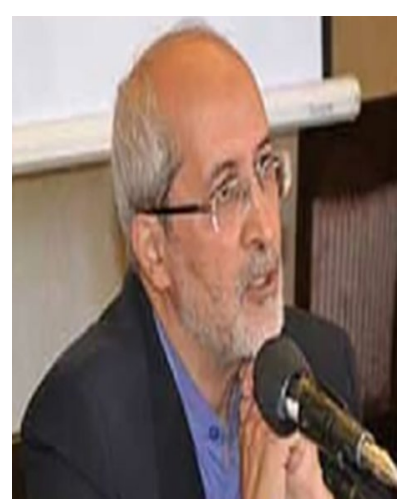

editorial member of our journal, and will be greatly missed. He was a first class expert in the field of concrete technology and the community has lost one of its most devoted members. His loss will be greatly felt by our editorial board, his students, his colleagues and family. Though we lost him, he will always be remembered as an excellent model in our life.

Editor-in-Chief: Ali Kaveh

On May 15, 2021, our colleague A.A. Ramezanianpour passed away and deeply shocked and saddened us. Professor A.A. Ramezanianpour was an active and highly devoted

Publisher's Note Springer Nature remains neutral with regard to jurisdictional claims in published maps and institutional affiliations.

Ali Kaveh

alikaveh@iust.ac.ir

1 School of Civil Engineering, Iran University of Science and Technology, Narmak, 16846-13114 Tehran, Iran 